\title{
Facioscapulohumeral muscular dystrophy: aspects of genetic counselling, acceptance of preclinical diagnosis, and fitness
}

\author{
Sabine Eggers, Maria Rita Passos-Bueno, Mayana Zatz
}

\begin{abstract}
A questionnaire about the interest in and demand for preclinical diagnosis for facioscapulohumeral muscular dystrophy (FSH) was sent to 46 patients. Most stated that they would have liked to have known their diagnosis earlier in order to seek more efficient help, to avoid strenuous activities, to prepare themselves emotionally, or to choose an appropriate profession. Similar arguments were used to explain their interest in preclinical diagnosis for their children. Most patients also favoured prenatal diagnosis although only two stated they would abort a pregnancy in the case of an affected fetus. Genetic counselling had apparently little influence on family planning. According to this study, FSH does not seem to reduce reproductive performance in our population.

(f Med Genet 1993;30:589-92)
\end{abstract}

Facioscapulohumeral muscular dystrophy (FSH) is an autosomal dominant genetic condition, with onset usually in the second decade, which causes a slowly progressive muscular weakness of variable severity, affecting the face, the upper limb girdle, and eventually the lower limbs. ${ }^{1}$ The estimated prevalence is approximately 1:21000. ${ }^{2}$ Padberg $^{3}$ estimated that $30 \%$ of $\mathrm{FSH}$ gene carriers are presymptomatic cases, unaware of their genetic status, as the gene has its maximum penetrance $(95 \%)$ above the age of $20 .{ }^{4}$

The recent localisation of the gene responsible for this condition at $4 \mathrm{q} 35^{5}$ will allow prenatal diagnosis as well as its detection before the appearance of clinical signs, leading to important psychological implications for genetic counselling.

In order to adapt genetic counselling to the potential of new technologies in molecular biology, the present study was undertaken to assess for the first time the demand for genetic counselling and prediction among FSH patients focusing on three aspects: (1) the retrospective effect and effectiveness of genetic counselling, (2) the acceptance of preclinical and prenatal diagnosis, and (3) the reproductive performance of affected adults.

\section{Subjects and methods}

A questionnaire containing direct questions about psychosocial aspects of genetic counselling, the interest in preclinical testing, as well as space for additional comments was sent to 46 literate FSH patients from 14 large Brazilian families, who had been referred to our centre for diagnosis and genetic counselling from 1979 to 1990 . Eleven more patients ascertained during this period could not answer our questionnaire because they were illiterate. Although 28 patients ( 17 of the 46 literates and the 11 illiterate patients) did not answer the questionnaire they could be included for fitness estimation because up to date information (such as current age and number of children) was obtained from them through telephone calls, home visits, or return of the patients or of their close relatives to our centre.

Diagnosis of FSH was based on clinical signs and course of the disease, serum enzyme determination (creatine kinase and pyruvate kinase), electromyography, muscle biopsy, and mode of inheritance.

Forty-two patients (from 11 families) belonged to families with definite dominant inheritance. In four patients (from three families) no affected person could be detected in previous generations, but their clinical signs and physical examination were typical of $\mathrm{FSH}$.

According to their muscular involvement and weakness at the time of genetic counselling, the patients' impairment was classified as: mild, when only the face was affected (grade 1); moderate, when the face and upper limbs were affected (grade 2); severe, when there was major disability of the upper/lower limbs (with difficulty in raising the arms, climbing stairs, running, standing up from a chair) and musculoskeletal deformity (grade 3).

During genetic counselling, issues such as the $50 \%$ recurrence risk for their offspring, the lack of effective treatment, and the unpredictability of the clinical course among those inheriting the FSH gene had been discussed with affected patients. The consultands were referred for physiotherapy and were advised about the importance of informing and bringing their at risk relatives to our centre.

The questions were designed to evaluate the following aspects: (1) their reaction after being informed about the diagnosis and genetic risks; (2) the impact of genetic counselling on their reproductive life; (3) their feelings regarding preclinical diagnosis and whether they felt their life would have been different had they known earlier that they carried the FSH gene; (4) their acceptance of prenatal and preclinical diagnosis; (5) their opinion about preclinical diagnosis for their young at risk children and the best age for discussion of a positive result. 
Table 1 Description of the patients who answered the questionnaire.

\begin{tabular}{|c|c|c|c|c|c|c|c|}
\hline \multirow[b]{2}{*}{ Code } & \multirow[b]{2}{*}{ Sex } & \multirow[b]{2}{*}{$\begin{array}{l}\text { Present } \\
\text { age }(y)\end{array}$} & \multirow[b]{2}{*}{$\begin{array}{c}\text { Age at } \\
\text { diagnosis } \\
(y)\end{array}$} & \multirow[b]{2}{*}{$\begin{array}{l}\text { Age at } \\
\text { GC } \\
(y)\end{array}$} & \multirow[b]{2}{*}{$\begin{array}{c}\text { Severity } \\
\text { of FSH at } \\
\text { GC }\end{array}$} & \multicolumn{2}{|c|}{ Children born } \\
\hline & & & & & & $\begin{array}{c}\text { Before } \\
\text { GC }\end{array}$ & After \\
\hline $\begin{array}{r}33 \\
2 \\
6 \\
39 \\
5 \\
8 \\
11 \\
18 \\
4 \\
43 \\
16 \\
41 \\
19\end{array}$ & $\begin{array}{l}M \\
M \\
M \\
M \\
M \\
M \\
M \\
M \\
M \\
M \\
M \\
M \\
M\end{array}$ & $\begin{array}{l}18 \\
26 \\
29 \\
30 \\
32 \\
34 \\
35 \\
35 \\
35 \\
37 \\
40 \\
41 \\
47\end{array}$ & $\begin{array}{l}13 \\
15 \\
25 \\
23 \\
18 \\
28 \\
19 \\
20 \\
35 \\
30 \\
20 \\
37 \\
36\end{array}$ & $\begin{array}{l}18 \\
18 \\
27 \\
29 \\
26 \\
28 \\
27 \\
26 \\
35 \\
36 \\
31 \\
37 \\
37\end{array}$ & $\begin{array}{l}1 \\
1 \\
1 \\
3 \\
2 \\
3 \\
2 \\
2 \\
1 \\
3 \\
2 \\
3 \\
2\end{array}$ & $\begin{array}{l}\overline{-} \\
\overline{-} \\
\bar{z} \\
\bar{z} \\
\overline{1} \\
\bar{z} \\
\overline{3}\end{array}$ & $\begin{array}{l}\overline{-} \\
\frac{1}{2} \\
\frac{1}{2} \\
\frac{1}{1} \\
\frac{2}{-} \\
-\end{array}$ \\
\hline Total & 13 & $33.8($ SD $7 \cdot 3)$ & $24 \cdot 5(\mathrm{SD} 8 \cdot 1)$ & $28.8(\operatorname{SD~} 6.4)$ & $2 \cdot 0$ & 0.31 & 0.69 \\
\hline $\begin{array}{r}27 \\
22 \\
3 \\
40 \\
7 \\
24 \\
23 \\
17 \\
29 \\
15 \\
14 \\
20 \\
38 \\
31 \\
1 \\
13\end{array}$ & $\begin{array}{l}\mathbf{F} \\
\mathbf{F} \\
\mathbf{F} \\
\mathbf{F} \\
\mathbf{F} \\
\mathbf{F} \\
\mathbf{F} \\
\mathbf{F} \\
\mathbf{F} \\
\mathbf{F} \\
\mathbf{F} \\
\mathbf{F} \\
\mathbf{F} \\
\mathbf{F} \\
\mathbf{F} \\
\mathbf{F}\end{array}$ & $\begin{array}{l}17 \\
18 \\
22 \\
22 \\
27 \\
31 \\
38 \\
39 \\
40 \\
46 \\
49 \\
55 \\
55 \\
55 \\
65 \\
74\end{array}$ & $\begin{array}{r}10 \\
8 \\
21 \\
17 \\
24 \\
17 \\
22 \\
30 \\
35 \\
37 \\
37 \\
46 \\
50 \\
43 \\
50 \\
65\end{array}$ & $\begin{array}{l}- \\
-11 \\
21 \\
24 \\
17 \\
29 \\
30 \\
37 \\
37 \\
40 \\
46 \\
54 \\
43 \\
50 \\
65\end{array}$ & $\begin{array}{l}1 \\
1 \\
1 \\
1 \\
1 \\
2 \\
3 \\
1 \\
3 \\
1 \\
3 \\
3 \\
2 \\
3 \\
1 \\
2\end{array}$ & $\begin{array}{l}- \\
\overline{-} \\
\overline{-} \\
\overline{1} \\
2 \\
2 \\
3 \\
2 \\
- \\
\overline{6} \\
4 \\
3 \\
8\end{array}$ & $\begin{array}{l}\overline{-} \\
\overline{-} \\
\overline{-} \\
\overline{2} \\
\overline{2} \\
\overline{-} \\
\overline{-} \\
\overline{-} \\
\overline{-} \\
\overline{-}\end{array}$ \\
\hline Total & 16 & $40 \cdot 8(\operatorname{SD~} 17 \cdot 3)$ & $32 \cdot 0(\mathrm{SD} 16 \cdot 1)$ & $34 \cdot 2(\mathrm{SD} \mathrm{15} \cdot 1)$ & $1 \cdot 81$ & 1.94 & $0 \cdot 25$ \\
\hline $\begin{array}{l}\text { Total } \\
M+\mathbf{F}\end{array}$ & 29 & $37.7(\mathrm{SD} 13.9)$ & $28.7(\mathrm{SD} \mathrm{13.5)}$ & $30 \cdot 7(\mathrm{SD} \mathrm{12 \cdot 7)}$ & 1.90 & $1 \cdot 21$ & 0.45 \\
\hline
\end{tabular}

GC = genetic counselling. Severity of FSH: mild (1), moderate (2), severe (3).

\section{Results}

The majority (16 females and 13 males, $63 \%$ ) of the 46 literate patients who were recontacted answered the questionnaire and information was obtained about six of the 17 who did not reply: three had moved to an unknown address, two had died, and one refused to answer the questions.

\section{EFFECT AND EFFECTIVENESS OF GENETIC} COUNSELLING

Females had six times more children (1.94) than males $(0.31)$ conceived before genetic counselling, but after counselling male patients had on average more children $(0.69)$ than females $(0 \cdot 25)$; the explanation could be that the males were on average 5.4 years younger than the females (table 1 ).

The answers to the 29 questionnaires are summarised below.

(1) How old were you when you received your diagnosis? Were you married and did you already have children at that time?

\begin{tabular}{clc}
\hline No of patients & \multicolumn{1}{c}{ Status } & Mean age \\
\hline $12(41.4 \%)$ & Single & $21.2 \mathrm{y}$ \\
$11(37.9 \%)$ & Married with children & $38.5 \mathrm{y}$ \\
$4(13.8 \%)$ & Married, without children & $33.0 \mathrm{y}$ \\
$2(6.9 \%)$ & No response &
\end{tabular}

(2) How did you feel when you were informed about your condition?

$10(34.5 \%)$ felt or still feel devatasted about it.

$6(20.7 \%)$ could not yet accept it.

$6(20.7 \%)$ accepted it easily.

$6(20.7 \%)$ were afraid of transmitting FSH to their children.

$6(20.7 \%)$ were afraid of
$1(3.4 \%)$ did not answer.

(3) What was the impact of genetic counselling on your family planning?

Only 11 patients $(37.9 \%)$ stated that genetic counselling had been important in two respects

Reducing (or planning to reduce) the number of children or not having any at all $(9 / 29=31 \cdot 0 \%)$.
Deciding not to get married $(2 / 29=6.9 \%)$.

(4) Do you think your life would have been different had you known your diagnosis earlier? How?

Yes $20(69.0 \%)$

$\begin{array}{lr}\text { No } & 20(20.7 \%) \\ \text { No answer } & 3(10.3 \%)\end{array}$

Among the 20 patients who answered this positively the explanations were:

"I would have looked for a more suitable profession, changed my marriage, and/or my whole life" $(8 / 29=27 \cdot 7 \%)$.

"I would have had fewer or no children at all"

$(7 / 29=24 \cdot 1 \%)$.

"I would have sought treatment earlier and/or tried to

prevent the progression of the disease" $(7 / 29=24 \cdot 1 \%)$

"I would have prepared myself emotionally, avoiding feelings

"1 would have prepared myself emotionally,

"I think life only changes with the onset of symptoms" $(1 / 29=3 \cdot 4 \%)$

(5) Did you notice any signs of FSH in your parents during your childhood? In case of a positive answer, how did this observation influence you? (23 patients had an affected mother or father, six patients had no affected parent either because their manifestation was too slight to be noticed and diagnosed, or because they had died early, or because the patient's disease had arisen from a new mutation.)

$15 / 23(65 \cdot 2 \%)$ were not aware of any sign in their affected parents (in three cases the parent's disease was only discovered after the establishment of the proband's diagnosis).

Of eight $(8 / 23=34.8 \%)$ cases who noticed the disease in one of their parents only five $(21.7 \%)$ were afraid of getting the disease and three $(13.0 \%)$ never worried about inheriting it.

(6) What would be the importance of early diagnosis for ourself?

Most of the patients $(26 / 29=89 \cdot 7 \%)$ replied that they would have liked to have known their diagnosis earlier, presenting the following arguments:

$10(34.5 \%)$ would seek treatment.

$6(20.7 \%)$ would try to avoid the progression of the disease. $6(20 \cdot 7 \%)$ would prepare themselves emotionally.

$2(6.9 \%)$ would avoid transmitting the disease on to their children.

$2(6.9 \%)$ would look for a more suitable profession.

(7) Would you like to know if your children have inherited the FSH gene? Why?

The majority $(25 / 29=86.2 \%)$ replied that they would like to know the genetic status of their children for the following reasons.

To seek treatment $(10 / 29=34.5 \%)$.

To prepare their child emotionally $(7 / 29=24 \cdot 1 \%)$

To avoid the progression of the disease $(6 / 29=20 \cdot 7 \%$ ) To decide whether or not to have more children $(2 / 29=6.9 \%)$

(8) In the case of a positive predictive result, when do you think this information should be transmitted to the children? As soon as the child can understand it $(20 / 29=69.0 \%)$.

As the first symptoms appear $(2 / 29=6.9 \%)$.

Some would not tell their children in order to avoid suffering in advance $(2 / 29=6.9 \%)$.

Before they get married $(1 / 29=3 \cdot 4 \%)$.

(9) Do you favour prenatal diagnosis?

Many $(22 / 29=75.9 \%)$ answered that they would favour prenatal diagnosis but only two patients $(2 / 29=7.9 \%)$ stated that they would abort a pregnancy in the case of an affected fetus.

The majority $(20 / 29=69 \cdot 0 \%)$ expressed some opinion or feelings in the open space left on the questionnaire. Several $(9 / 29=31.0 \%)$ were interested in more information about their condition and necessary adaptations for their daily life, $5 / 29(=17 \cdot 2 \%)$ wrote that they were very anxious about the discovery of an efficient treatment, and $4 / 29(=13.8 \%)$ expressed various feelings related to their condition. Only two $(2 / 29=6.9 \%)$ patients asked explicitly for early diagnosis for their children.

\section{REPRODUCTIVE PERFORMANCE AND FITNESS} ESTIMATES

Data on 57 FSH cases referred to our centre since 1979 are summarised in table 2 .

The 13 male patients who answered the questionnaire (group A) are much younger (33.8 years) and more severely affected (2.0) than the 12 males who did not answer (group 
Table 2 Age, severity of FSH, and number of children born to FSH patients and to their healthy sibs.

\begin{tabular}{|c|c|c|c|c|c|c|}
\hline \multicolumn{3}{|l|}{ Subjects } & \multirow{2}{*}{$\begin{array}{r}\text { No } \\
13 \\
16 \\
12 \\
5 \\
10 \\
1\end{array}$} & \multirow{2}{*}{$\begin{array}{c}\begin{array}{c}\text { Mean age* } \\
\text { (SD) }\end{array} \\
33 \cdot 8(7 \cdot 2) \\
40 \cdot 8(17 \cdot 3) \\
43 \cdot 0(18 \cdot 1) \\
42 \cdot 8(15 \cdot 4) \\
54 \cdot 2(15 \cdot 2) \\
54 \cdot 0(0 \cdot 0)\end{array}$} & \multirow{2}{*}{$\begin{array}{c}\begin{array}{c}\text { Mean severity } \\
\text { at GC }\end{array} \\
2 \cdot 0 \\
1.8 \\
1.5 \\
2 \cdot 4 \\
2.4 \\
2 \cdot 0\end{array}$} & \multirow{2}{*}{$\begin{array}{c}\begin{array}{c}\text { Mean no of } \\
\text { children born* }\end{array} \\
1.0 \\
2.2 \\
2.6 \\
2.8 \\
5 \cdot 1 \\
2.0\end{array}$} \\
\hline $\begin{array}{l}\text { FSH } \\
\text { literates } \\
\text { FSH } \\
\text { illiterates }\end{array}$ & $\begin{array}{l}\text { (A) } \\
\text { (B) }\end{array}$ & $\begin{array}{l}\text { Males } \\
\text { Females } \\
\text { Males } \\
\text { Females } \\
\text { Males } \\
\text { Females }\end{array}$ & & & & \\
\hline FSH patients & & $\begin{array}{l}\text { Males } \\
\text { Females }\end{array}$ & $\begin{array}{l}35 \\
22\end{array}$ & $\begin{array}{l}44 \cdot 5(15 \cdot 9) \\
44 \cdot 7(14 \cdot 7)\end{array}$ & $\begin{array}{l}1 \cdot 9 \\
2 \cdot 0\end{array}$ & $\begin{array}{l}2 \cdot 8 \\
2 \cdot 3\end{array}$ \\
\hline \multicolumn{3}{|c|}{ Total FSH patients } & 57 & $44 \cdot 6(15 \cdot 5)$ & 1.9 & $2 \cdot 6$ \\
\hline Healthy sibs & & $\begin{array}{l}\text { Males } \\
\text { Females }\end{array}$ & $\begin{array}{l}36 \\
52\end{array}$ & $\begin{array}{l}49 \cdot 1(14 \cdot 8) \\
45 \cdot 9(13 \cdot 3)\end{array}$ & $\overline{-}$ & $\begin{array}{l}2 \cdot 3 \\
2 \cdot 2\end{array}$ \\
\hline Total healthy & sibs & & 88 & $47 \cdot 7(13.9)$ & - & $2 \cdot 3$ \\
\hline
\end{tabular}

$\mathrm{GC}=$ genetic counselling. $(\mathrm{A})=$ those who answered the questionnaire. $(\mathrm{B})=$ those who did not answer the questionnaire. ${ }^{*}=$ up to date information.

B, 43.0 years, 1.5 grade of severity). The fact that the illiterate patients were much older ( $54 \cdot 2$ years) and had on average more children $(5 \cdot 1)$ could be a consequence of improving education in our country towards a smaller family size.

For fitness analysis the mean number of children born to all $57 \mathrm{FSH}$ patients was compared with the number of children conceived by their healthy sibs $(n=88)$ of comparable age. No significant difference $(2.57 /$ $2 \cdot 26=1 \cdot 137, t=0.75, \mathrm{p}>0.05)$ in reproductive performance was observed in FSH patients as compared to their healthy sibs. A slight difference in fitness was seen according to the gender of the patients: $2 \cdot 77 / 2 \cdot 30=1 \cdot 204$ for affected males and $2 \cdot 32 / 2 \cdot 21=1 \cdot 050$ for females, but it was not significant $(t=0.62$ $\mathrm{p}>0.05)$.

\section{Discussion}

EFFECTIVENESS OF GENETIC COUNSELLING

Although one third of our FSH patients answered that they would have reduced the number or not have had children at all, genetic counselling had little effect on their reproductive performance because in most cases it was received relatively late $(30.7$ years) and almost $40 \%$ of the patients already had children at that time. As seen in table 1 , the lower birth rate among female patients after genetic counselling ( 0.25 children per patient) in comparison with the males $(0.69)$ can be explained by the difference in the mean age at which women (34.2 (SD 15.1) years) and men (28.8 (SD 6.4) years) were counselled.

\section{SEVERITY OF THE PHENOTYPE}

Among those who replied, the average severity of the disease in females did not differ significantly $(t=0.31, \mathrm{p}>0.05)$ from that observed in males (table 1). There was also no difference in severity between males and females when all 57 patients were taken together (table 2 ). However, males were referred for genetic counselling on average 5.4 years earlier than females. This suggests either a bias towards more severely affected or younger males, or that more middle aged affected women sought counselling and were more motivated (through having a greater concern about their children and grandchildren) to reply to the questionnaire than affected men of the same age.

\section{TREATMENT}

Although all patients had been told that FSH is still an untreatable disease, almost one third still believed that they could have sought an effective treatment had they known about their condition earlier. Their hope for treatment is, naturally, very great.

Interestingly, a quarter of our patients thought that they could have prevented the disease itself or at least its progression had they avoided physical stress, contact with "environmental agents that awaken the gene responsible for FSH", or by better nutrition.

\section{EMOTIONAL PREPARATION}

Several patients felt that emotional preparation was important in particular because there is no active treatment available. The lack of psychological support might explain why $20 \%$ of our patients do not yet accept their condition even five years after diagnosis, which reinforces the importance of such support for families affected with a progressive disease.

\section{INTEREST IN PREDICTIVE DIAGNOSIS IN FSH}

Previous investigations have shown that identification of asymptomatic carriers and prenatal diagnosis are effective in preventing the birth of new affected cases in other severe forms of muscular dystrophy, such as the $\mathrm{X}$ linked Duchenne type. ${ }^{6-9}$ However, the benefit, as opposed to the negative emoticnal impact, brought by early diagnosis (through neonatal screening programmes) in progressive untreatable diseases such as DMD is still controversial.

We are not aware of similar studies in muscular dystrophies with late onset such as FSH. Detection of heterozygotes for autosomal dominant traits such as Huntington's disease (HD) is a complicated issue, which has been widely discussed. Although recent studies suggested that predictive testing for HD could be accepted by $2 / 3$ of at risk persons, ${ }^{10-13}$ a much lower percentage (less than $20 \%$ ) have actually requested testing since it has been available. ${ }^{1415}$

However, HD differs from FSH in several respects, including the much lower penetrance of the HD gene in young adults, in particular during reproductive age, and the rapid and devastating progression after onset.

In the present study $25 / 29(86 \cdot 2 \%)$ patients showed interest in genetic testing for their children. However, the small percentage of patients $(6.7 \%)$ who stated that predictive testing is important for family planning suggests that they seem to be more worried about early treatment than to prevent the birth of more affected persons in their family.

Most of our patients $(27 / 29=93 \cdot 1 \%)$ did not mention aborting a pregnancy in the case of a positive test. One possible explanation might 
be the feeling of guilt or denial in an affected parent who aborts a child who, although handicapped, would be able to lead an almost normal life.

As the risk for $\mathrm{FSH}$ in an asymptomatic young adult is only $5 \%$, it would be expected that genetic testing would be requested (1) to reassure asymptomatic young adults and children that they do not carry the defective gene; (2) to confirm or not the presence of the gene in the few cases of clinical uncertainty; (3) to offer early diagnosis in at risk children; and (4) more rarely for prenatal diagnosis.

\section{FITNESS IN FSH PATIENTS}

In accordance with previous investigations ${ }^{316}$ no reduction of reproductive performance was observed among our FSH patients $(f=1 \cdot 137)$, in contrast to our limb-girdle muscular dystrophy (LGMD) families where we found a much lower fitness in females $(0.45)$ than in males $(0.98) .{ }^{12}$

It will be interesting to confirm, through personal interviews, the wish for taking predictive testing (both preclinical and prenatal) and its influence on reproductive performance in our young FSH patients, as well as comparing such results with observations from other populations. A similar study for myotonic dystrophy, whose gene has recently been identified, ${ }^{18}$ will be of great interest.

The authors are very grateful for the collaboration of the families. We also thank Dr Debora Rapaport, Dr Mariz Vainzof, Dr Rita Pavanello, and Martha A B O Lima for their helpful discussions and Reinaldo Takata and Thais Zago for their technical support. We are also grateful for the constructive comments of the anonymous reviewer. This research was supported by FAPESP, CNPq, and ABDIM.

1 Walton J. Disorders of voluntary muscle. Edinburgh: Churchill Livingstone, 1988.

2 Lunt PW, Harper PS. Genetic counselling in facioscapulohumeral muscular dystrophy. $\mathcal{F}$ Med Genet 1991;28:65564 .

3 Padberg G. Facioscapulohumeral disease. MD thesis, University of Leiden, 1982

4 Lunt PW, Compston DAS, Harper PS. Estimation of age dependent penetrance in facioscapulohumeral muscular dystrophy by minimising ascertainment bias. $\mathcal{f}$ Med Genet 989;26:755-60.

5 Wijmenga C, Padberg GW, Moerer P. Mapping of facioscapulohumeral muscular dystrophy gene to chromosome 4q35-qter by multipoint linkage and in situ hybridization. Genomics 1992;9:570-5.

6 Skinner R, Emery AEH, Scheuerbrandt G, Syme J. Feasibility of newborn screening for Duchenne muscular dystrophy. $\mathcal{f}$ Med Genet 1982;9:1-3.

7 Zatz M. Effects of genetic counselling on Duchenne muscular dystrophy families in Brazil. Am $\mathcal{F}$ Med Genet 1973;15:483-90

8 Forrest SM, Cross GS, Thomas NST. Effective strategy for prenatal prediction of Duchenne and Becker muscular prenatal prediction of Duchenne
dystrophy. Lancet $1987 ; 2: 1294-6$.

9 Smith RA, Sibert JR, Wallace SJ, Harper PS. Early diagnosis and secondary prevention of Duchenne muscular gnosis and secondary prevention of Duche

10 Kessler S, Field T, Worth L, Mosberger H. Attitudes of persons at risk for Huntington disease toward predictive
pesler $\mathrm{H}$, Field $\mathrm{T}$, Worth $\mathrm{L}$, Mosberger $\mathrm{H}$. Attites of testing. Am F Med Genet 1987;26:259-70.

11 Mastromauro C, Myers RH, Berkman B. Attitudes of at risk persons toward presymptomatic testing in Huntington disease. Am $\mathcal{F}$ Med Genet 1987;26:271-82.

12 Meissen GJ, Berchek RL. Intended use of predictive testing by those at risk for Huntington disease. Am $\mathcal{F}$ Med Genet 1987;26:283-93.

13 Markel DS, Young AB, Penny JB. At-risk person's attitudes toward presymptomatic and prenatal testing of Huntington disease in Michigan $\mathrm{Am} 7$ Med Genet 1987;26:295-305.

14 Craufurd D, Dodge A, Kerzin-Storrar L, Harris R. Uptake of presymptomatic predictive testing for Huntington's of presymptomatic predictive

15 Meissen GJ, Mastromauro CA, Kiely DK, McNamara DS, Myers RH. Understanding the decision to take the predictive test for Huntington disease. Am f Med Genet 1991;39:404-10

16 Prot J. Genetic-epidemiological studies in progressive muscular dystrophy. $f$ Med Genet 1971;8:90-5.

17 Passos-Bueno MR, Vainzof M, Pavanello RCM, PavanelloFilho I, Lima MABO, Zatz M. Limb-girdle syndrome: a genetic study of 22 large Brazilian families, comparison with $\mathrm{X}$-linked Duchenne and Becker dystrophies. $f$ Neurol Sci 1991;103:65-75.

18 Harley HG, Brook JD, Rundle SA, et al. Expansion of an unstable DNA region and phenotypic variation in myotonic dystrophy. Nature 1992;355:545-6. 